\title{
Gas hazard: an often neglected natural risk in volcanic areas
}

\author{
W. D'Alessandro \\ Istituto Nazionale di Geofisica e Vulcanologia, Sezione di Palermo, \\ Palermo, Italy
}

\begin{abstract}
Volcanic areas release huge amounts of gases, which apart from having important influences on the global climate could have strong impact on human health. Gases have both acute and chronic effects. Carbon Dioxide and Sulphur gases are the main gases responsible for acute mortality due to their asphyxiating and/or toxic properties. On the contrary Mercury and Radon have important chronic effects respectively for its toxicity and radioactivity.

The problem has long been neglected until the "Lake Nyos" catastrophe in 1986, in which about 1700 people were killed by a volcanic $\mathrm{CO}_{2}$ emission, attracted the worldwide attention of the mass media.

In this paper we present some studies on gas hazards in three different volcanic systems chosen for their different activity status: Mt. Etna (Italy), characterised by frequent activity with a mean $\mathrm{CO}_{2}$ emission of about $450 \mathrm{~kg} \mathrm{~s}^{-1}$; Pantelleria island (Italy) at present in quiescent status and a $\mathrm{CO}_{2}$ emission of about $12 \mathrm{~kg} \mathrm{~s}^{-1}$; and Sousaki (Greece) a recent (Quaternary) but now extinct volcano with a $\mathrm{CO}_{2}$ emission of about $0.6 \mathrm{~kg} \mathrm{~s}^{-1}$. In all three systems the main problems arise from $\mathrm{CO}_{2}$ emissions while secondary problems are due to $\mathrm{SO}_{2}$ and $\mathrm{Hg}$ (Etna), $\mathrm{H}_{2} \mathrm{~S}$ (Sousaki) and Rn (Pantelleria).
\end{abstract}

Keywords: gas hazard, Carbon Dioxide, Sulphur gases, Radon, Mercury.

\section{Introduction}

Pliny the Elder, who perished during the 79 A.D. eruption of Vesuvius in Italy, is possibly the most famous known victim of volcanic gases. The description of his death, made by his nephew Pliny the Younger (Letter 16, 6), clearly points to cardio-respiratory collapse of a person with chronic respiratory disease. 
Although it is unclear if the fatal causes were volcanic gases or fine suspended ash or even a heart attack, the description closely resembles that reported for one of the victims of volcanic gases at Aso volcano in Japan in recent times, who suffered from pulmonary emphysema [1].

Gas manifestations have been recognized since olden times and often sanctuaries were built near them since the Neolithic to get protection against them from divinities. In these sanctuaries sometimes oracles gave their responses under the narcotic effect of elevated $\mathrm{CO}_{2}$ concentrations. An important sanctuary for example was placed at the Palici Lake in Sicily ( $5^{\text {th }}$ cent. B.C.). The abundant $\mathrm{CO}_{2}$ released from its shores and trough its waters was used to test the truth of persons [2]. Standing on the shore of the lake the person had to swear in the name of the sanctuary's gods looking to the sky, and then had to touch the waters with his hands. If he had no consequences he was saying the truth. Probably in wind free days there was a higher proportion of 'liars'. Nowadays fluxes in the area are still very high [3] but no signs of the sanctuary is still present, the lake was dried up and $\mathrm{CO}_{2}$ is industrially exploited for gas addition to beverages.

On February $20^{\text {th }} 1979$ at the onset of eruptive activity of Sinila crater on Dieng Plateau, Indonesia, 142 persons, fleeing from the nearby Batur village, died asphyxiated by a cloud of $\mathrm{CO}_{2}$-rich volcanic gas rolling down the flank of the volcano [4]. But it was not until 1986 that a wide public knew about the risk of volcanic gases. On August $21^{\text {st }}$ of that year about 1700 people were killed and 850 injured by a massive gas release from Lake Nyos, Cameroon [5]. The gas release of this volcanic crater lake, composed almost exclusively of $\mathrm{CO}_{2}$, was not related to any paroxysmal volcanic activity. The release occurred on a calm night and the gas cloud, heavier than air, flowed in a valley that was more than $250 \mathrm{~m}$ below the surface level of the lake.

Recently Witham [6] published a new database of volcanic disasters and incidents of the $20^{\text {th }}$ century. Of the 491 reported events $11 \%$ were referred to volcanic gases, accounting for 2016 (2\% of the total) of the killed and 2860 $(18 \%)$ of the injured people. As the author himself states, this database has to be improved and completed and indeed only one of the many incidents occurred in Italy has been reported. But it is equally impressive to learn that the Lake Nyos disaster ranks at the $8^{\text {th }}$ place for the number of dead and at the $5^{\text {th }}$ place for the number of injured in this database.

An important research project aiming at the study of diffuse degassing of the whole Italian peninsula financed by Italian Civil Protection is currently in progress [7]. The new awareness of the importance of determining the risk connected with natural gases mainly of volcanic origin probably derives from the expansion of Rome's metropolitan area well within the area of Albani Hills. This recent, possibly still active, volcanic area is characterised by anomalous gas fluxes, which led to some fatal outcomes in the last years [8].

Sometimes the risk associated to gases is enhanced by improper human operations. For example an area within the urban area of Rome is naturally protected from high gas fluxes from the soil by shallow impermeable sediments. But excavation or drilling operations sometimes perforate these impermeable layers leading to massive gas outflows [8]. One of these episodes evidenced that 
both of the medical and fire brigade structures were (and probably still are) unprepared to face this kind of emergency. The doctors in fact didn't recognize the $\mathrm{CO}_{2}$ intoxication of 7 persons that lived close to the drilled well, and attributed ailments to collective hallucination because no clinical signs were still present at the emergency station. Returning to their homes these persons escaped death only by chance and were eventually hospitalised. On the other hand the remedy applied by fire brigade, to drill additional wells trying to exhaust the gas source, had as the only consequence to exacerbate the problem that was fixed only sealing all the drilled wells with the injection of special cements [8].

\section{Hazardous gases}

\subsection{Carbon dioxide}

Carbon dioxide is the more abundant gas, after water vapour, released by volcanic activity. Total $\mathrm{CO}_{2}$ output of the different volcanic systems span over a wide range of values, from about $450 \mathrm{~kg} \mathrm{~s}^{-1}$ of Mt. Etna (Italy) and Popocatepetl (Mexico) down to values of less than $0.1 \mathrm{~kg} \mathrm{~s}^{-1}$ (Iwoyama, Japan) [9]. Open conduit volcanoes, like Mt. Etna and Popocatepetl, emit this gas mainly through the craters. On the contrary volcanoes with closed conduit, even if characterised by intense fumarolic activity, release $\mathrm{CO}_{2}$ almost exclusively through diffuse soil degassing [9]. Carbon dioxide annually released by volcanoes at the global scale was estimated in about $300 \mathrm{Tg}$, which represents only a small fraction (1\%) of the $\mathrm{CO}_{2}$ released by human activities [10]. The geographical distribution of natural $\mathrm{CO}_{2}$ release corresponds prevailingly to areas of active or recent $(<10$ Ma) volcanism and seismicity [10]. Carbon dioxide has different origins: biogenic (respiration), hydrocarbon oxidation, thermal or chemical breakdown of limestone and mantle degassing. The first two processes very rarely create dangerous natural $\mathrm{CO}_{2}$ accumulations. Carbonate minerals in the crust can release huge quantities of $\mathrm{CO}_{2}$ both through thermal breakdown due to high geothermal gradients and through reaction with acid hydrothermal fluids. Magma ascent from the earth's mantle is a very efficient $\mathrm{CO}_{2}$ degassing process. Mantle-generated magmas contain up to $1.5 \%$ by weight of $\mathrm{CO}_{2}$, but its low solubility leads to early (deep) gas separation during ascent of magmas. Considering that $\mathrm{CO}_{2}$-depleted magmas could eventually solidify within the crust, some volcanic system, like Stromboli Island (Italy), emit on long time average by weight more gas than lava.

Normal $\mathrm{CO}_{2}$ concentration in the atmosphere at sea level is about $350 \mathrm{ppm}$ (by volume) but its concentration can rise if production exceeds consumption and dissipation. Being heavier than air, in high flux areas, $\mathrm{CO}_{2}$ can accumulate in topographic depressions and enclosures reaching concentrations as high as $100 \%$. Carbon dioxide concentrations higher than $10 \%$ can be lethal to humans and animals, and at concentrations above $20-30 \%$ even a few breaths can very quickly lead to unconsciousness and death from acute hypoxia, severe acidosis and respiratory paralysis [11]. Therefore, poorly ventilated places below and 
immediately above ground such as caves, galleries, cellars, water wells, etc. can be very dangerous in areas of anomalous $\mathrm{CO}_{2}$ emissions.

\subsection{Sulphur gases}

Sulphur gases follow carbon dioxide in order of abundance in volcanic gases. The most important species are $\mathrm{SO}_{2}$ and $\mathrm{H}_{2} \mathrm{~S}$ and their relative abundance is fixed by the thermodynamic parameters within the volcanic system (pressure, temperature, oxygen fugacity). Low temperatures and the presence of a hydrothermal system favour $\mathrm{H}_{2} \mathrm{~S}$. Open conduit volcanoes display high $\mathrm{SO}_{2} / \mathrm{H}_{2} \mathrm{~S}$ ratios $(>20)$ while on the other hand volcanoes with low temperature fumarolic activity display low ratios $(<0.1)$.

Sulfur dioxide is a highly irritant gas. In healthy persons 5 to $10 \mathrm{ppm} \mathrm{SO}_{2}$ cause eye, nose and throat irritation while 30 to $40 \mathrm{ppm}$ can lead to respiratory failure. In individuals with bronchial asthma or other chronic lung diseases exposure to much lower levels $(0.25$ to $0.5 \mathrm{ppm})$ can be life threatening [1]. Concentrations of up to a few ppm can easily be achieved close to active volcanic craters. Indeed six fatalities due to $\mathrm{SO}_{2}$ have been documented at Mt. Aso volcano, Japan in the period 1989-1997, while other 59 persons had to be hospitalized in the period 1980-1995 [1]. Five of the dead and 29 of the injured suffered from chronic lung diseases, evidencing the higher risk for this class of people. In 1996 a monitoring system for the measurement of $\mathrm{SO}_{2}$ in air was set up in the crater area. No one could enter the area when $\mathrm{SO}_{2}$ level was exceeding $5 \mathrm{ppm}$, while an advise was given when it was exceeding $0.2 \mathrm{ppm}$ for more than 5 min discouraging the visit of the crater. People suffering of respiratory and cardiovascular diseases were asked to vacate the area when $\mathrm{SO}_{2}$ was exceeding $2.5 \mathrm{ppm}$ for more then $5 \mathrm{~min}$. But such precautions were not able to save the lives of two persons on 23 November 1997. So it was decided to apply a more rigorous criterion, forbidding the access if $\mathrm{SO}_{2}$ was exceeding $0.2 \mathrm{ppm}$ for more than $1 \mathrm{~min}$ or in the presence of instantaneous peaks exceeding $5 \mathrm{ppm}$ [1].

Hydrogen sulphide is both an irritant and asphyxiant gas. Levels of up to $20 \mathrm{ppm}$ have generally no effects on healthy people while for asthmatic persons this level have to be reduced to $2 \mathrm{ppm}$ [12]. Concentrations above $20 \mathrm{ppm}$ cause irritative effects on eyes and respiratory tract, above 50-100 ppm neurotoxic effects appear and 500-1000 ppm are considered of immediate life danger [12]. Although the human odour threshold is very low $(0.02 \mathrm{ppm})$ the warning signal is lost above $150 \mathrm{ppm}$ because of olfactory nerve paralysis by $\mathrm{H}_{2} \mathrm{~S}$ itself. Like $\mathrm{CO}_{2}$ also $\mathrm{H}_{2} \mathrm{~S}$, being heavier than air, tend to accumulate in closed and/or depressed areas. Some of the fatal incidents with volcanic gases were attributed to the effect of $\mathrm{H}_{2} \mathrm{~S}$ released by low temperature fumarolic vents or by gas bubbling through thermal springs. Furthermore, although not conclusive, some studies evidenced also health effects from chronic exposure to $\mathrm{H}_{2} \mathrm{~S}(0.1-2 \mathrm{ppm})$ in the city of Rotorua (New Zealand), which is built on a geothermal field [13].

\subsection{Radon}

Radon is a natural radioactive gas being and intermediate product of the radioactive decay series of Uranium and Thorium. Radon can easily enter the 
human body by inhalation. Radioactivity of Radon and of its decay products has been linked to an increase in the risk of developing lung cancer. Only smoking is a greater risk factor for lung cancer with respect to Radon inhalation [14].

The concentration of Radon in the indoor air and in soil atmosphere depends from many factors. One the most important is the content of parent elements (Radium, Uranium, Thorium etc.) in the rocks of the subsoil or of the building material. Furthermore, release and transport of radon are controlled by nature and alteration of the containing minerals, moisture content, and by the nature (i.e. carbon dioxide gas or groundwater) and flux of a carrier fluid [14].

In volcanic and geothermal areas higher risk of Radon accumulation occur where differentiated magmas, enriched in parent elements, are involved, where geothermal alteration is widespread and where anomalous gas fluxes are present.

\subsection{Mercury}

Mercury is a highly volatile, bioaccumulating toxic trace metal strongly enriched in volcanic and geothermal emanations. The contribution of volcanic activity (about $700 \mathrm{Mg} \mathrm{yr}^{-1}$ ), although highly debated, represents $20-40 \%$ of the global natural emission [15]. Very high mercury concentrations in air (up to $40 \mu \mathrm{g} \mathrm{m}^{-3}$ ) have been measured in volcanic and geothermal areas of Hawaii and of Iceland [16], well above the guideline value of $1 \mu \mathrm{g} \mathrm{m}^{-3}$ recommended by WHO for general population exposition and sometimes also above the occupational longterm exposure limit of $25 \mu \mathrm{g} \mathrm{m}^{-3}$. Although mercury accumulation in professionally exposed persons (volcanologists, guides, employed of the geothermal industry) has been demonstrated [17], no study on the neurotoxic effects of volcanic-derived mercury in this population has been until now performed.

\section{Gas hazard at selected volcanoes}

\subsection{Mt. Etna}

Mount Etna, located in eastern Sicily, is the largest strato-volcano in Europe (3300 m a.s.l.; base, $60-40 \mathrm{~km}$ ) and one of the most active in the world. It grew in proximity to the collision boundary of the African and Eurasian continental plates, from repeated eruptions of alkali basalts-hawaiites over the last $200 \mathrm{ka}$ [18]. Its recent activity is characterized by permanent open-conduit passive degassing, interrupted by paroxysmal activity (effusive to moderately explosive) at the summit craters and/or newly formed flank craters. At present, Etna's central conduit feeds four summit craters called Voragine, Bocca Nuova, SouthEast and North-East. Degassing at the summit craters has continued without interruption in the last few decades, although only rarely have all the craters been degassing contemporaneously. Mt. Etna is considered, on long time average, the greatest point source of many volatile compounds to the atmosphere [18]. 


\subsubsection{Lower flanks}

Etna emits yearly about $1 \mathrm{Tg}$ of $\mathrm{CO}_{2}$ diffusely through the soils of its flanks. This huge amount represents about $10 \%$ of the total $\mathrm{CO}_{2}$ output, the greatest part being released through the summit craters. Spatial distribution of diffuse degassing is strongly controlled by the tectonic setting of the volcanic system and two anomalous degassing areas on the $\mathrm{SW}$ and on the $\mathrm{E}$ lower flanks have been recognized [18]. In these areas very high values of $\mathrm{CO}_{2}$ fluxes from the soil (up to $500 \mathrm{~g} \mathrm{~m}^{-2} \mathrm{~d}^{-1}$ ) and of $\mathrm{CO}_{2}$ partial pressure in groundwaters (up to $5 \mathrm{~atm}$ ) are measured. These areas are also densely settled and intensively cultivated due to the high fertility of the soils and to their huge groundwater resources. Groundwater is exploited through wells and drainage galleries. Until recent times wells were excavated with large diameters (generally $2 \mathrm{~m}$ ) up to depths of 400 $\mathrm{m}$. These wells, still diffused and in use, in the two anomalous degassing areas display often dangerous accumulations of $\mathrm{CO}_{2}$ on their bottoms. People in the area know the problem very well and all operations inside the wells are generally made by expert persons under steady air-pumping, in worse cases with two or more independent pumping systems connected to autonomous electric generators. Such precautions warrant a reasonable safety and no fatal accidents have been registered at least in the last 30 years period. But in the last years an increasing trend of land abandonment left many of these wells unattended so that unprepared persons could get inside unaware of the high risk. For the mitigation of this risk it would be very important: i) to take census of all the old wells, at least, in the two anomalous degassing areas and ii) regularly control their state and if abandoned close all possible access and evidence the danger with adequate warning notices.

Groundwaters are also extracted from the flanks of Mt. Etna with drainage galleries (or horizontal wells). A few tens of these galleries have length of more than $1000 \mathrm{~m}$ and water yields of $0.1-1 \mathrm{~m}^{3} \mathrm{~s}^{-1}$. Some of these galleries, built in the anomalous degassing areas, emit together with the groundwater also huge quantities of $\mathrm{CO}_{2}$, which represents a big problem not only inside the gallery but also outside its exit. The gas, in fact, tend to follow the water flowing in the canal at the exit of the gallery and in wind free days maintain dangerous concentrations of some \% up to distances of some tens of meters.

In May 1993 one fatal incident was registered at the gallery known as 'Ponteferro' near the village of S. Venerina on the eastern flank of the volcano. There was no eye-witness of the episode but the reconstruction points to the huge gas release as one of the main causes. The victim was an old man that kneeing down to collect water from the canal with a bottle, loosed consciousness due to the high $\mathrm{CO}_{2}$ concentration and eventually drowned falling in the canal. The access to the area, where many people come to collect drinking water, was immediately restricted to supervised periods and the canal was covered with a metal grid.

\subsubsection{Summit crater area}

The access to the summit area is generally unrestricted in periods of low volcanic activity. On the crater rims in the downwind direction lethal gas concentrations 
can easily been reached. But only volcanologists have sometimes the necessity to go inside the volcanic gas plume to collect samples and in this case they have to wear efficient gas masks and leave the area as soon as possible. Strong winds and water vapour condensation that evidences the plume help all other people to avoid areas with dangerous gas concentrations. Dangerous conditions could arise in rare cases, when wind blows very mildly or changes rapidly direction, but fortunately only healthy people reach the crater rims after a hard climb and they can stand higher concentrations. But there're two areas close to the summit craters, Pizzi Deneri (2800 $\mathrm{m}$ a.s.1. about $2 \mathrm{~km} \mathrm{NE}$ from the summit craters) and Torre del Filosofo (2900 $\mathrm{m}$ a.s.1. about $1 \mathrm{~km} \mathrm{~S}$ from the summit craters), where tourists are transported with all-wheel drive busses. Often between these tourists there're elderly people that possibly suffer of chronic lung disease. No danger advice is given to these people of the possible effects of volcanic gases. In my opinion it is only by chance than until now there have been no serious consequences. The few measurements made in these two areas, in fact, gave monthly average values between 0.2 and $0.5 \mathrm{ppm}$ [19], which are life threatening for persons affected by chronic lung disease [1]. For this reason it would be desirable to set up a warning and monitoring system like that of Mt. Aso in Japan [1].

Torre del Filosofo is also an area of anomalous soil degassing connected to old eruptive fractures. There is also an abandoned hut that was used for long time as shelter for volcanological surveillance instruments. One of its rooms, partially below ground level, used in winter times as emergency toilet, suffered for long time of $\mathrm{CO}_{2}$ accumulation but fortunately ventilation was always enough to prevent dangerous concentrations. In November 2003, during an eruption the hut was completely covered by volcanic ash. In the following summer the hut was partially uncovered to show its rests to the tourists, creating an access to some of its rooms. But these rooms that could represent an attractive shelter for excursionists during winter, in recent times (summer 2005) displayed very dangerous $\mathrm{CO}_{2}$ concentrations up to some percent.

Recent measurements evidenced also high concentrations of mercury in the summit crater area (E. Bagnato and S. Giammanco - personal communication) with values of some $\mu \mathrm{g} \mathrm{m}^{-3}$ in the volcanic plume and some hundreds of $\mathrm{ng} \mathrm{m}^{-3}$ in the atmosphere in the Torre del Filosofo area. In this case the most exposed persons are not the tourists but the guides that spend a lot of time in the area.

\subsection{Pantelleria Island}

The island of Pantelleria represents the top of a large active volcano developed on the African continental crust. The volcano is located between Sicily and Tunisia, within NW-SE trending tectonic depressions related to the opening of a rift system developed during the Neogene-Quaternary [20]. The island is dominantly composed by volcanics showing compositional variations ranging from basalts to peralkaline rhyolites (pantellerites) ranging in age from $320 \mathrm{ka}$ to the present. The volcanic activity of the island is mainly characterized by violent explosive eruptions and secondarily by basaltic effusive activity [20]. Its last eruption occurred in 1891 about $5 \mathrm{~km} \mathrm{NW}$ off its coast. The island is at present 
characterized by widespread occurrence of surface hydrothermal manifestations (fumaroles and thermal springs) [21].

Also Pantelleria island displays two anomalous degassing areas with cold (mofettes, bubbling gases) and hot (fumaroles) gas manifestations and areas of strong $\mathrm{CO}_{2}$ fluxes from the soil [21]. One of these mofettes is placed in a topographically depressed area near Lake Specchio di Venere. In wind-free days $\mathrm{CO}_{2}$ accumulates near the ground being a lethal trap for small animals. Such conditions could be very dangerous also for human that would lay down resting on the shores of the lake. Fortunately in recent times warning signals have been set up, but it would probably be safer also to fence the most dangerous area (some tens of $\mathrm{m}^{2}$ ). Furthermore in the inner of the island there're many natural saunas exploiting the heath of fumaroles. Almost all of them are fed by fumarolic gases composed exclusively by water vapour and atmospheric air, but a few, within one of the anomalous degassing areas, contain also dangerous concentrations of $\mathrm{CO}_{2}$. These improvised saunas are built by foreign people that live on the island only on holidays and are not aware of this type of risk.

Recently Radon measurements in soils and in dwellings of the island evidenced for most of the island very high values [22]. The highest values were detected in central and southern part of the island where the most radionucliderich rocks crop out. The higher natural radiation doses absorbed by the local population has been considered an additional risk factor in developing some kind of cancer and indeed a statistical study confirmed their higher incidence [Brai M. personal communication].

\subsection{Sousaki}

The Sousaki area is located in Greece, about $65 \mathrm{~km}$ west from Athens, near the Isthmus of Corinth and represents the NW end of the active Aegean volcanic arc. Here, sparse outcrops of dacitic rocks are the remnants of late-Pliocene to Quaternary volcanic activity (4.0 - 2.3 Ma [23]), while widespread fumarolic alteration and warm $\left(35-45^{\circ} \mathrm{C}\right)$ gas emissions are still recognizable. Drilling exploration assessed the presence of a low enthalpy geothermal field.

In the area showing the highest hydrothermal alteration, located along a narrow valley, several small caves were dug in the past century to extract hydrothermal alteration minerals (alunite, magnesite, sulfur). Some of these caves display at present hydrothermal gas emission from their bottoms. The gases, being denser than atmospheric air, flow on the grounds of the caves and eventually spill out from the mouth of the caves dispersing in the atmosphere after descending the flanks of the valley. The gases are composed of more than $90 \%$ of $\mathrm{CO}_{2}$ and have also high concentrations of $\mathrm{H}_{2} \mathrm{~S}(1000-6000 \mathrm{ppm})$. Hazardous concentrations of $\mathrm{CO}_{2}$ and $\mathrm{H}_{2} \mathrm{~S}$ are measured inside the caves were dead small animals are always found. But $\mathrm{H}_{2} \mathrm{~S}$ dispersing in the surrounding atmosphere displays concentrations of some ppm that produces surely annoying smell and represents also a potential chronic health impact for the nearby living persons. 


\section{Conclusions}

In the $20^{\text {th }}$ century more than 2000 persons died and nearly 3000 were injured by volcanic gases. The most dangerous gas species is $\mathrm{CO}_{2}$, responsible of more than $90 \%$ of the victims and of the worst episodes (Lake Nyos and Lake Monoun, Cameroon and Dieng Plateau, Indonesia), but lethal episodes are also attributed to sulphur gases $\left(\mathrm{SO}_{2}\right.$ and $\left.\mathrm{H}_{2} \mathrm{~S}\right)$. Furthermore also Mercury and Radon have dangerous chronic effects on human health due to their toxicity and radioactivity. Gas hazard is often disregarded because it is almost always connected to low or absent volcanic activity when attention is low. But we know that volcanic gases and especially $\mathrm{CO}_{2}$ can be released by volcanic systems up to some million years after volcanic activity ended. It is therefore important not to underestimate potential risks and the effort of the Italian scientific community under the patronage of Civil Protection for the understanding and mitigation of this natural risk goes in the right direction.

\section{References}

[1] Ng'Walali, P.M., Koreeda, A., Kibayashi, K., Tsunenari, S., Fatalities by inhalation of volcanic gas at Mt. Aso crater in Kumamoto, Japan, Legal Medicine 1, 180-184, 1999.

[2] Ferrara, F., Memoria sopra il lago de Palici ora lago Naftia in Sicilia, Reale Stamperia, Palermo, 1805.

[3] De Gregorio, S., Diliberto, I.S., Giammanco, S., Gurrieri, S. \& Valenza, M., Tectonic control over large-scale diffuse degassing in eastern Sicily (Italy), Geofluids 2, 273-284, 2002.

[4] Le Guern, F., Tazieff, H. \& Faivre-Pierret, R., An example of health hazard: people killed by gas during a phreatic eruption: Dieng Plateau (Java, Indonesia), February $20^{\text {th }}$ 1979. Bulletin Volcanologique 45, 153156, 1982.

[5] Baxter, P.J., Kapila, M. \& Mfonfu, D., Lake Nyos disaster, Cameroon, 1986: the medical effects of large scale emission of carbon dioxide? British Medical Journal 298, 1437-1441, 1989.

[6] Witham, C.S., Volcanic disasters and incidents: A new database, Journal of Volcanology and Geothermal Research 148, 191-233, 2005.

[7] http://www.ingv.it/progettiSV/Progetti/Vulcanologici/vulcanologici_con_ frame.htm

[8] Carapezza, M.L., Ranaldi, M. \& Tarchini, L., Gas hazard in the Roman area: soil $\mathrm{CO}_{2}$ discharge and accidents induced by uncontrolled shallow boreholes, Abstract Book of the $8^{\text {th }}$ International Conference on Gas Geochemistry ICGG 8, Palermo and Milazzo, Italy, 2-8 October 2005, p. 12, 2005.

[9] Pecoraino, G., Brusca, L., D’Alessandro, W., Giammanco, S., Inguaggiato, S. \& Longo, M., Total $\mathrm{CO}_{2}$ output from Ischia Island volcano (Italy). Geochemical Journal 39, 451-458, 2005. 
[10] Mörner, N.A. \& Etiope, G., Carbon degassing from the lithosphere, Global and Planetary Change 33, 185-203, 2002.

[11] Henderson, Y. \& Haggard, H.W., Noxious gases, Reinhold Pub. Co, 1943.

[12] World Health Organization, Hydrogen Sulfide: Human health aspects, Concise International Chemical Assessment Document 53, 26 pp., 2003.

[13] Bates, M.N., Garret, N. \& Shoemack, P., Investigation of health effects of Hydrogen Sulfide from a geothermal source, Archives of Environmental Health 57, 405-411, 2002.

[14] Appleton, J.D., Radon in air and water, in: Essentials of Medical Geology (Selinus, O., Alloway, B. Centeno, J.A., Finkelman, R.B., Fuge, R., Lindh, U. \& Smedley, P. eds.), Elsevier, 2005.

[15] Pyle, D.M. \& Mather, T.A., The importance of volcanic emissions for the global atmospheric mercury cycle, Atmospheric Environment 37, 5115 5124, 2003.

[16] Siegel, S.M. \& Siegel, B.Z., Geothermal hazard. Mercury emission, Environmental Science and Technology 9, 473-474, 1975.

[17] Siegel B.Z., \& Siegel, S.M., Mercury in human hair: uncertainties in the meaning and significance of 'unexposed' and 'exposed' in sample population, Water Air and Soil Pollution 26, 191-199, 1985.

[18] Calvari, S., Bonaccorso, A., Coltelli, M., Del Negro, C. \& Falsaperla, S. (eds.) Etna Volcano Laboratory, Geophysical Monography Series, AGU, 143, 2004.

[19] Aiuppa, A., D’Alessandro, W., Federico, C., Ferm, M. \& Valenza M., Volcanic plume monitoring at Mount Etna by diffusive (passive) sampling. Journal of Geophysical Research 109(D21), D21308, 2004.

[20] Civetta, L., Cornette, Y., Gillot, P.Y. \& Orsi, G., The eruptive history of Pantelleria (Sicily Channel) in the last $50 \mathrm{ka}$, Bulletin of Volcanology 50, 47-57.

[21] Favara, R., Giammanco, S., Inguaggiato, S. \& Pecoraino, G., Preliminary estimate of $\mathrm{CO}_{2}$ output from Pantelleria island volcano (Sicily, Italy): evidence of active mantle degassing, Applied Geochemistry 16, 883-894, 2000 .

[22] Cinti, D., Pizzino, L., Galli, G., Quattrocchi, F. \& Voltattorni, N., Radon and thoron soil survey in the Pantelleria island: first results. Abstract book of the Annual Assembly of Italian National Group for Volcanology, Naples, 20-22 December 2004.

[23] Pe-Piper, G. \& Hatzipanagiotou, K., The Pliocene volcanic rocks of Crommyonia, western Greece and their implications for the early evolution of the South Aegean arc, Geological Magazine 134, 55-66, 1997. 